\title{
Turkey's Libya Policy: Achievements and Challenges
}

\author{
ISMAIL NUMAN TELCi \\ Sakarya University,Turkey \\ ORCID No: 0000-0001-8397-8503
}

ABSTRACT Libya has been witnessing a long and destructive civil war since the fall of Qaddafi in 2011. While countries like the United Arab Emirates, Egypt and France have an extremely damaging role in Libya, Turkey and Qatar has been trying to focus on ending the conflict and establishing a stable democratic country. Hafter's invasion attempt, supported by the UAE and Egypt, failed as a result of Turkey's intervention. In this regard, it would be correct to say that the peace process and political dialogue has only become possible with Turkey's involvement in the Libyan equation. In Libya, where tribal ties are already effective, and centralization is weak, long-term conflicts have deeply shaken social cohesion. Furthermore, international actors have remained uninterested in Libya or preferred to fuel the problem rather than solve it. All of these factors, made it difficult for Turkey to implement its plans in Libya. Nevertheless, both Libya and Turkey have achieved major gains since the beginning of the year. In this context, this study aims to underscore the challenges of aforementioned process and consequently acquisitions of both sides.

Keywords: Libya, Turkey, Government of National Accord, Libyan National Army, France, United Arab Emirates 
Introduction

W

ith the assassination of $\mathrm{Mu}-$ ammar Qaddafi in 2011, the violence of the conflicts in Libya increased. The NATO-led military operation in 2011 sparked controversy about whether the intervention would succeed. Since the time of the military operation, efforts to establish peace have been undertaken by leading international organizations; however, low intensity clashes in Libya have continued despite these efforts and started to increase in 2014.

Geopolitical, conjunctural, and ideological developments have contributed to forming an environment conducive for the increase of conflict in Libya. In geopolitical terms, Libya's long coastline on the Mediterranean and its low population compared to its land area are factors that may increase the possibility of conflict. Considering cyclical developments, Libya's importance has increased in parallel with the exploration of large amounts of hydrocarbon reserves in the Eastern Mediterranean. And, considering ideological developments, the country has become open to the influence of international actors with the division of the Libyan army into different factions after the Arab uprisings.

One of the major factors that make the Libyan conflict more important internationally is the Eastern Mediterranean issue. Libya has a coastline of approximately $1,770 \mathrm{~km}$ on the Mediterranean. Thus, the stability of
Libya and the Eastern Mediterranean are closely intertwined. After the 2000s, the efforts of countries with coasts on the Eastern Mediterranean to determine the borders of the continental shelf and establish exclusive economic zones have increased, and the instability of the countries in the region has added to the complexity of determining which countries can establish partnerships with whom. Considering the ongoing civil war in Syria, the Israeli-Palestinian conflict, and Egypt's situation under Sisi's rule, Libya's importance has become even more evident.

Given Libya's geographical location and geostrategic importance, the conflict there has become a critical foreign policy issue for regional actors in the Eastern Mediterranean. In this regard, Turkey has emerged as one of the most influential regional actors in the Libyan conflict. Ankara is pursuing a constructive agenda for the future of Libya as Turkey allies itself with the internationally recognized government based in Tripoli. This commentary aims to give a brief overview of Turkey's involvement in the Libyan conflict by taking a closer look at the main characteristics of Ankara's policy and achievements as well as its challenges in the Libyan conflict.

\section{Turkish Policy in Libya: Turning Points}

There have been multiple turning points in the ongoing war in Libya. For many reasons, Turkey's interest 
in the war in Libya has increased recently and, in parallel with this development, the turning points in the war in Libya have become associated with the growing partnership between Turkey and the Government of National Accord (GNA). Turkey, which has an approximately 1,600 km long Mediterranean cost, signed a deal with Libya's GNA on November 27, 2019 , on the delimitation of maritime jurisdiction areas in the Mediterranean following article 102 of the UN Charter. ${ }^{1}$

The Turkish-Libyan deal took effect on December 8, 2019. ${ }^{2}$ The agreement constituted one of the crucial turning points of the struggle in Libya and the Eastern Mediterranean. But the deal sparked an unfair and unfounded backlash in the region, both from countries with coasts on the Eastern Mediterranean and from other regional actors. France, Greece, the Greek Administration of Southern Cyprus (GASC) and Egypt did not hesitate to declare a statement criticizing the deal and saying that it doesn't bear any legal consequence. ${ }^{3}$ The United Arab Emirates (UAE) made similar statements later on. The European Union (EU) also opposed the Turkish-Libya deal, claiming that it constitutes an infringement based on the Law of the Sea. ${ }^{4}$ However, in late 2020, the UN General Secretary registered the Turkish-Libya deal, representing a legal victory for Turkey and the GNA. ${ }^{5}$

Turkey increased its support to Libya in the wake of the deal, and signed an agreement with the GNA regard-

\section{One of the preliminary reasons Haftar received foreign support was the dominance of his illegitimate forces over particular oil fields in Libya}

ing military and technical assistance as well. ${ }^{6}$ The military and technical assistance agreement that came after the maritime deal consolidated Turkish efforts to establish peace and stability in Libya. As part of the agreement, 'a quick reaction force' that works with the police and military in Libya was established, and the two states ensured that cooperation on intelligence and the defense industry would proceed accordingly. ${ }^{7}$

In parallel with Turkish entrance into the Libyan scene, and in keeping with internationally established standards, Khalifa Haftar's so-called Libyan National Army (LNA) and its affiliated, illegitimate forces quickly started to lose ground. In 2019, Haftar's offensive toward Tripoli was halted following grave realities on the ground, which forced the LNA to withdraw from Tarhouna only to redeploy to Jufra. ${ }^{8}$ With Turkish support, the GNA gradually became the main authority in the regions that had been regained from the LNA. The UN's ceasefire and dialogue efforts increased due to the intensifying tensions on the battlefield. When Haftar's offensives toward the capital failed, the defense had to start alongside the withdraw- 


\section{As the legitimate authority}

representative of Libya,

the GNA has been trying to

uphold its unified position to

represent the Libyan people

against a common enemy al. Haftar forces, especially those that redeployed to Jufra and its surroundings, had trouble holding ground there due to an immediate counter-offensive by the GNA.

On August 21, 2020, a ceasefire was reached on the lines of Sirte and Jufra, but it could not be implemented fully. ${ }^{9}$ The ceasefire aimed to achieve the demilitarization of Sirte and Jufra, where intense clashes had been going on. The ceasefire remained fragile, however, due to foreign support for Haftar's illegitimate forces. In September and October, the Libyan army had stated that Russia had sent Syrian fighters to Libya to support Haftar; ${ }^{10}$ these and other mercenaries affiliated with Haftar refused to accept the ceasefire and made maneuvers to disrupt the ceasefire environment.

One of the preliminary reasons Haftar received foreign support was the dominance of his illegitimate forces over particular oil fields in Libya. According to international customs and national regulations, oil in Libya should only be sold by the Libyan National Oil Company (NOC). ${ }^{11}$ However, those controlling the oil fields and regions under Haftar's control defied this order.

Turkey gives weight to the Libya file, which has formed one of the key points of its foreign policy since 2020 . While contacts are being made with international actors to ensure peace and stability in Libya, the GNA is supported in the field in the presence of the UN. Due to the military and technical support Turkey has provided to the GNA, Tripoli has been saved from falling into Haftar's hands, and rapid progress toward the Sirte-Jufra line has been made. Despite all these developments, however, issues like protecting Libya's unitary structure and warding off militias, which Turkey has emphasized, seem unlikely to be solved under the current circumstances in the short run. It makes sense to mention a few internal and external challenges for Turkey's Libya policy at this point.

\section{Fragmented Political Actors and the Challenges to Turkey's Role}

During the Qaddafi era, Libya's institutions were destabilized, and a fragmented, non-hierarchical structure was established to centralize authority and prevent those institutions from posing a threat to Qaddafi's rule. It can be argued that tribalism is still a very powerful phenomenon and a basic motivation in the social structure of Libya. The inclusion of tribes in modern political systems, who have lived in deserts and vast territories for centuries free and without the strict control of any central political 

has a military background and who tends to focus on military issues despite his civilian position, would not possibly work in coordination with Sarraj for a long time even though he would return to his job.

This crisis was an important development, as it weakened the unified stance of Libya's legitimate leadership. Similar cases of diverging agendas were also witnessed in the cases of oil production and the appointment of high-ranking defense officers by the Sarraj leadership. The lack of unified vision and commitment to working together among members of the GNA constitutes one of the most critical challenges for Turkey, as Ankara urges the GNA to take constructive, unified steps by exercising its legitimate power.

\section{External Challenges to Turkey's Objectives in Libya}

Turkey and Libya have historical, political, economic, and cultural ties. Turkey was one of the first countries to immediately recognize the state of Libya following its foundation as an independent state in 1951. During the turbulent period in the Middle East following the Arab uprisings, Turkey did not refrain from pursuing relations with Libya. Through its diplomatic missions, Turkey has been a staunch supporter and a vigilant observer of Libya's stability on the road to democracy. Since 2014, Libya's political disputes have turned into a deadly civil war, where regional and international actors have increasingly involved. As part of its diplomatic efforts to establish peace and bring stability to Libya, Turkey was one of the participants in forming the Skhirat Agreement (Libyan Political Agreement), and Ankara has provided continuous support to the UN-recognized GNA. ${ }^{12}$

From 2014 onward, illegitimate forces under the leadership of former General Khalifa Haftar gained ground in the East of Libya. In particular, the illegitimate forces started to be active in garnering support from local and regional allies, and from international actors. Haftar's forces have been supported primarily by Russia, Egypt, France, Saudi Arabia, and the UAE, especially in his offensive toward the capital, Tripoli, in April 2019. The GNA, in turn, has been supported by Turkey and Qatar. ${ }^{13}$

When the external factors are considered, the Trump Administration, which drove the CIA-linked Haftar to the stage, called for a ceasefire and used the initiative to lead the peace talks, mediated between the two sides on the production and export of oil-but still does not follow a clear policy in finding a solution. In the meantime, Russia, France, the UAE, and Egypt are continuing with their policies that threaten peace and stability in Libya. Given the conflux of multiple external agendas, Turkey's policies that prioritize stability and peace face major difficulties.

Although the U.S.' Libya policies after 2011 have been consistent, they have also been self-contradictory. After 
the assassination of the U.S. Ambassador in Libya, John Christopher Stevens, the U.S. withdrew from Libya to a great extent and returned militarily to face the emergence of ISIS in the region. Washington, which had driven Haftar to the field, turned a blind eye to his war crimes. Ghassan Salamé, who served as UN Special Representative for Libya between June 2017 and March 2020, criticized the U.S.' indecisive policy in a program he joined on October 15, 2020. He stated that at the Berlin Conference Haftar had approached him and said, "John Bolton told me to be quick if I wanted to take Tripoli, I do not understand why you criticize me this much." ${ }^{\prime 4}$ Trump's meeting with Haftar on April 4, 2020 a few days after his attempts to invade Tripoli, is a clear sign of U.S.' support, which has been known from the first day on.

When Haftar failed to achieve a military victory in Libya, the Trump Administration halted support for his forces. In the following period, Haftar became increasingly engaged with Russia, and his presence in the field was integrated with Wagner mercenaries. The inclusion of NATO member France in the Russian camp in addition to Egypt and the UAE, the U.S.' most significant allies in the region, worried the U.S. Washington led the ceasefire in Sirte and Jufra on August 21, 2020. The U.S. Embassy in Libya stated on September 12, 2020 that Haftar's blockade on oil production and sales would be lifted; six days after this statement, Haftar lifted the eight-month embargo on oil production.

\section{The inclusion of NATO member France in the Russian camp in addition to Egypt and the UAE, the U.S.' most significant allies in the region, worried the U.S.}

The U.S.' Libya policy is not solution-oriented and instead pursues stabilization. Russia, which is unofficially present in Libya through the Wagner group, in contrast to its official military presence in Syria, clearly does not consider the ceasefire of August 21 a long-term settlement, as it continues providing Haftar with military equipment. Russia has increasingly been one of Haftar's primary backers in his fight against the GNA. ${ }^{15}$ Pursuing a two-track strategy in Libya, Russia strengthened Haftar's failed efforts to claim Tripoli. The first track of Russia's strategy in Libya is established by Wagner. The second is established on the premise of supporting Haftar's offensives both on the ground and in the diplomatic arena. In this respect, Haftar has been shouldered by Vladimir Putin who bets against any American initiative in the Libyan conflict.

Another primary international backer of Haftar is France. Although French President Emmanuel Macron has been quite explicit in expressing France's support for a peaceful solution for Libya, his intimate relations with and diplomatic support to Haftar call into question France's overall aims. While Macron blocked 


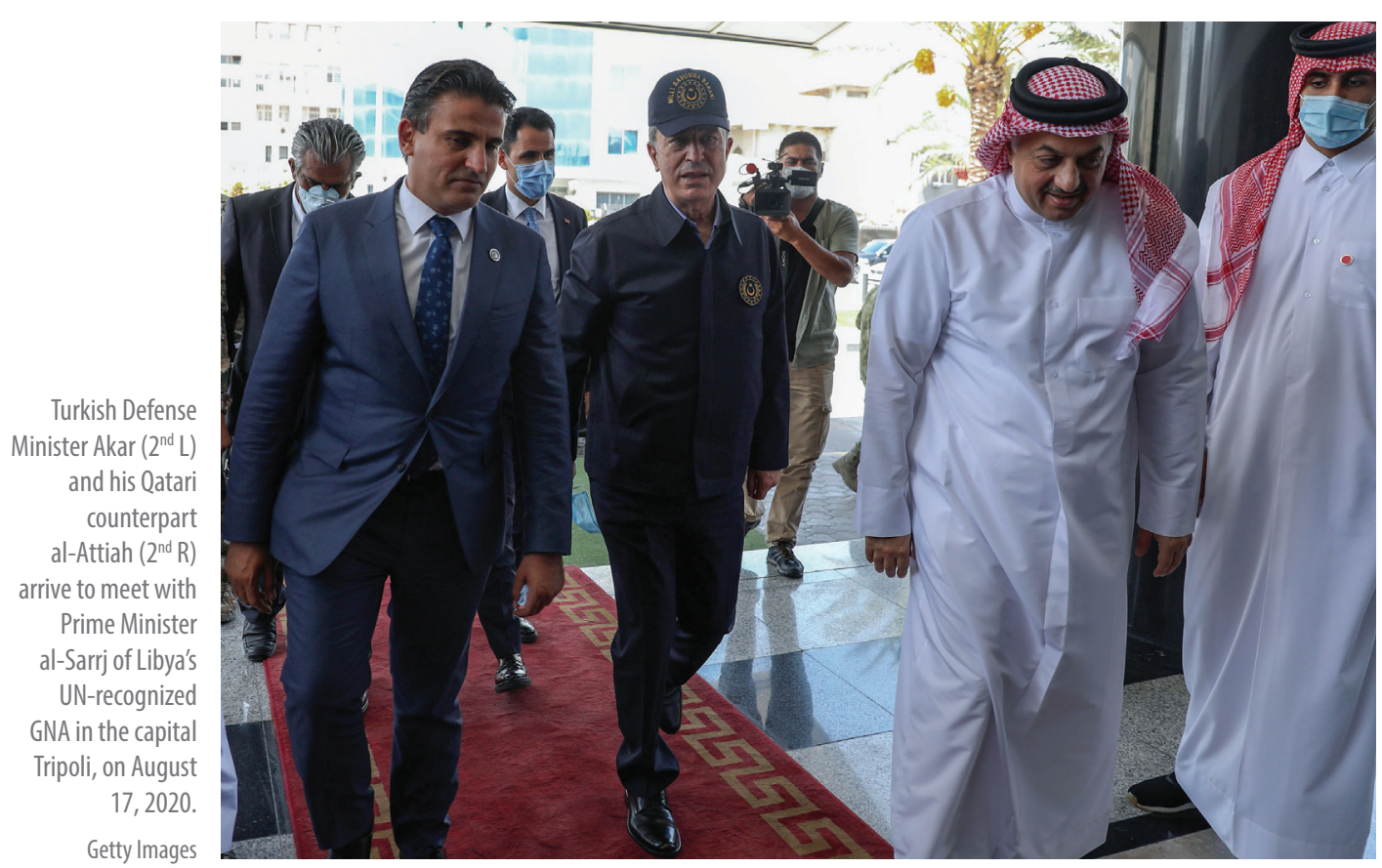

most of the international efforts to resolve the conflict in Libya, Paris has also consistently undermined the stability of the international legitimate government (GNA) in Tripoli. As an important NATO ally, France's support to Haftar, who is strengthening its relationship with Russia increasingly, has led to some questions about the future of France within the North Atlantic Alliance.

Along with their international partners, Saudi Arabia, Egypt, and the UAE have been Haftar's most ardent supporters. Many reports have claimed that the so-called LNA was established with UAE support and that its military capability is reliant on the UAE for air support. ${ }^{16}$ It has been revealed that the UAE provided Haftar with Chinese-made Wing
Loong II Unmanned Aerial Vehicles (UAVs) and Russian-made Panstir S-1 air defense systems. ${ }^{17}$ Egyptian autocrat Abdel Fattah el-Sisi has also funneled weapons to Haftar, and there has been tactical and logistical cooperation between Haftar and Sisi. ${ }^{18}$ Saudi Arabia, in turn, has provided Haftar with the financial capability to buy the cooperation of tribal leaders.

Although Haftar has been supported financially, logistically, and militarily by a set of regional and international partners, most of the territorial gains the illegitimate forces have recorded have been overturned by the strengthening of the Libyan people. Yet Libya, which has its own internal conflicts between East and West, has yet to formulate a coherent structure 
among its factions. The involvement of multiple actors and their efforts to benefit from the ongoing war has made the process intractable. As a result, the search for a political solution and the negotiations for a lasting ceasefire, which have remained constantly on the agenda in Libya, have so far failed to reach a final result. Although Ankara prioritizes the Libya file, the complex structure in Libya remains a major obstacle to Turkey's efforts to maintain peace and stability.

\section{Turkey's Achievements in Libya}

Following the Turkish Parliament's approval of the decision to keep troops in Libya on January 2, 2020, the de facto withdrawal of Haftar's militias began. ${ }^{19}$ This decision and its results were clear gains for Turkey. Ankara has been keen on achieving a sustainable victory against Haftar's forces by supporting the GNA. As recent developments reveal, Turkey was able to reach its objectives ${ }^{20}$ not only in the Libyan field, but also in the Eastern Mediterranean. Moreover, as Turkey maintained its determined position, the Tripoli leadership has been able to provide security and trust to the Libyan people. It has to be noted that Turkey has made practical, tangible, political and diplomatic achievements toward resolving the Libyan conflict.

With the discovery of hydrocarbon resources in the Eastern Mediterranean in the early 2000s, the countries in the region began taking steps to
Turkey will be present in both the Northern and Southern parts of the Mediterranean, as its military presence at those bases will not be limited to times of conflict

establish their maritime jurisdiction. Greece and the GASC made efforts to deprive Turkey of this wealth by excluding it from the region. The GASC signed a maritime agreement with Egypt in 2003, Lebanon in 2007, and Israel in 2010. Events like the Eastern Mediterranean Gas Forum, to which Turkey was not invited, were organized within this frame; it too aimed to deprive Turkey of its natural rights in the region. ${ }^{21}$ Turkey signed a Continental Shelf Delimitation Agreement with the Turkish Republic of Northern Cyprus in 2011, and later signed an agreement with Libya in 2019, in keeping with international law and in response to the ambitious countries of the region, especially Greece and the GASC.

Turkey's Minister of Energy and Natural Resources, Fatih Dönmez, stated at the end of May, 2020, that Turkish Petroleum Corporation (Türkiye Petrolleri Anonim Ortaklığı, TPAO) had applied to explore oil in the license-granted areas within the scope of the agreement with Libya, and that its first activities would start within months. ${ }^{22}$ A high-level delegation that included Turkey's Minister of 
Foreign Affairs Mevlüt Çavuşoğlu, Turkish Presidential Spokesperson İbrahim Kalın, then the Finance Minister Berat Albayrak, and the Director of the National Intelligence Organization Hakan Fidan paid an unannounced visit to Libya on June 17, 2020 to discuss significant issues concerning energy and banking. ${ }^{23}$ The efforts of Haftar's militias to impose embargoes, especially on electricity, in areas under GNA control has prompted Turkish companies to provide services for Libya in the field of energy.

Libya's cooperation with Turkish companies, particularly construction companies, goes back to 1972 . It is estimated that the total value of the contracts signed by Turkish companies until 2011 is around $\$ 40$ billion. The GNA, which controls the Western part of Libya, has prioritized and initiated reconstruction and repair activities. The head of the Turkish Contractors Association, Mithat Yenigün, underlined in an October 2020 statement that the projects set to take place in Libya in the upcoming era will be worth at least $\$ 50$ billion. ${ }^{24}$ Considering Turkish companies' successful experiences in Libya over the past half-century and President Sarraj's special invitations to Turkish companies during his visits to Ankara and İstanbul, it is not hard to predict that the Libyan market will contribute significantly to the Turkish economy.

Akıncı and Bayraktar, Turkish UAVs and UCAVs (Unmanned Combat Aerial Vehicle) respectively, played a major role in confronting Haftar's attack on Tripoli and approaching the Sirte-Jufra line after maintaining control in the Western part of Libya. The UAVs, which undertook more detailed and difficult tasks in Libya compared to their operations in Idlib, have successfully proven their worth in terms of both defense and attack capabilities. Necessary modifications were made based on the experience gained from the field, paving the way for the development of more sophisticated systems. The videos provided to Haftar's militias by the UAE of Russian-made air defense systems being destroyed by Turkish UCAVs became known worldwide in the media. ${ }^{25} \mathrm{~A}$ video circulated by the press unit of Operation Volcano of Rage, affiliated with the GNA, showed the destruction of an air defense system in the city of Terhune, and significant press organizations like The Washington Post, Le Monde, and Die Welt have drawn attention to the success of Turkey's domestically made UAVs.

Therefore, it can be concluded that Turkey's support for the GNA also represents a step forward for its indigenous defense industry. Turkey's unmanned combat aerial vehicle, the Bayraktar TB2 attracted particular attention and achieved its first export success after the Syrian operations Euphrates Shield and Olive Branch. When the Akıncı UAV completed its check flights successfully, Turkey became one of the top 3-4 most efficient countries in the field of UAVs. With the capacity to remain in the air up to 24 hours at 40,000 feet, the Akıncı is also capable of carrying 1.5 tons of 
cargo. The Akıncı increases the operational power of the Turkish army and reduces the warplanes' load of operation and flight costs, and has also become a significant option for other countries.

It seems certain that Turkey's domestic defense industry products, especially the UAVs and UCAVs that proved themselves in Libya, will appeal to a larger market in the upcoming era. In this context, Turkey's 2023 goal of $\$ 10.2$ billion in exports from its indigenous defense and aerospace industry seems likely to be achieved, thanks to its successful intervention in Libya.

The Libyan experience has brought abstract but significant gains in the long run for Turkey, a country that has increasingly become a regional game-changer. Turkey's National Intelligence Organization (MİT), which made it possible to give the Libyan army support in tactical and technical terms, achieved significant success and increased its capability to perform overseas operations. President Erdoğan, who highlighted the organization's role in Libya at the opening ceremony of MİT's new center in January 2020, stated that the intelligence and operational support provided by MITT was game-changing. ${ }^{26}$ Put simply, Turkey's success in a conflict zone overseas with multiple actors through its national means has increased Ankara's influence in international politics.

It is widely accepted that the GNA has succeeded in holding Western Libya

\section{By establishing strong} partnerships with the legitimate authorities in Libya, Turkey will continue to be an active supporter of peace and stability in the country

thanks to Turkish support. Turkey will continue to have a military presence in the Misrata and al-Watiya air bases to maintain this dominance. Turkey will be present in both the Northern and Southern parts of the Mediterranean, as its military presence at those bases will not be limited to times of conflict. Thanks to its strategic cooperation with the GNA, and keeping Libya's geopolitical location in mind, Turkish air forces in al-Watiya have gained the ability to perform sudden operations in African countries, especially Egypt, Tunisia, Algeria, Sudan, and Chad.

All of these gains obtained by Turkey have resulted in its being the greatest international stakeholder in the Libya case. As a result of Turkish authorities' intense efforts in the Libya case, particularly the Ministries of Foreign Affairs and National Defense, the international arena has acknowledged Turkey's priorities as well as objectives on Libya remarkably. It has become apparent that no Libya plan can be designed without Turkey. Turkey's success in the field of diplomacy will undoubtedly not be limited to Libya. Turkey's breakthrough in terms 


\section{Turkey will continue to} support the legitimate demands of the people, rather than the autocratic projects aspiring to dominate the

\section{region}

tive role by supporting the internationally recognized government and strengthening its institutions. Turkish contribution to Libya's state-building efforts is crucial in establishing a democratic political structure. While Turkey has been calling for regional and international actors to positively engage in the Libyan conflict, it has also been encouraging the Libyan parties to sit together to find a common ground to overcome the long-running stalemate.

matched by its breakthrough in diplomacy, and its success in Libya has accelerated this process.

To conclude, Turkey, which does not follow an imperial or a self-seeking agenda, has provided the necessary help for Libya to the full extent of its power, acting on its responsibility as a neighbor in the Mediterranean and in keeping with its historical ties to the Libyan people. Turkey's continuing solidarity with the Libyan people is evident in its refusal to abandon their fate to a warlord who spent a significant part of his life in America.

\section{Conclusion}

The Libyan conflict has turned into a complex situation where the intervention of regional and international actors became a reality. The nature of the involvement of these actors differs significantly. On the one hand countries like the UAE, Egypt, and France have been increasingly contributing to the destabilization of Libya, while on the other hand Turkey and Qatar have been playing a very construc-
In this sense, Turkey is a strong supporter of the local peace initiatives and meetings that are held to find a peaceful and Libyan-based solution to the ongoing complexity. Both regional (Bouznika Conferences) and international (Berlin Conference) attempts have tried to come up with concrete outcomes. The most recent of such initiatives, the Libya Political Dialogue forum, took place in Tunisia on November 9, 2020, with the participation of the representatives of the warring parties. The forum, where foreign countries were not directly on the table and the broadest scope of participants from Libya took place, was a crucial event in the hope to find a lasting solution to the crisis. The forum resulted with a number of concrete decisions such as the one about the next election, which is set for December 24, 2021. Despite some positive steps taken in the Libyan Dialogue forum, there are many issues that still remain unclear.

As these initiatives unfold, Turkey continues to be one of the most constructive external parties in Libya. 
Like many countries in the region, Turkey is negatively affected by Middle Eastern instability, and Ankara must ensure its security by pursuing a foreign policy designed to meet its national agenda. In this sense, Turkey does not evaluate the Libyan conflict and the Eastern Mediterranean question separately. The regional projects aimed at limiting Turkey's role in the Eastern Mediterranean could also be found in Libya. But Turkish foreign policy, while abiding by international law, is responding to the legitimate demands of the people in the region and preventing those regional projects from becoming a reality.

By establishing strong partnerships with the legitimate authorities in Libya, Turkey will continue to be an active supporter of peace and stability in the country. Ankara also supports constructive international dialogue and the platforms that aim to establish a fair future for the region. Turkey will continue to support the legitimate demands of the people, rather than the autocratic projects aspiring to dominate the region.

\section{Endnotes}

1. Daren Butler and Tuvan Gumrukcu, "Turkey Signs Maritime Boundaries Deal with Libya," Reuters, (November 28, 2019), retrieved October 2, 2020, from https://www.reuters.com/article/ us-turkey-libya-idUSKBN1Y213I.

2. Servet Günerigök, "UN Registers Turkey-Libya Maritime Deal," Anadolu Agency, (October 1, 2020), retrieved October 2, 2020, from https://www.aa. com.tr/en/middle-east/un-registers-turkey-libya-maritime-deal/1992682; "Memorandum of Understanding between the Government of the Republic of Turkey and the Government of $\mathrm{Na}$ tional Accord-State of Libya on Delimitation of the Maritime Jurisdiction Areas in the Mediterra- nean," The United Nations, (November 27, 2019), retrieved October 3, 2020, from https://www. un.org/Depts/los/LEGISLATIONANDTREATIES/ STATEFILES/TUR.htm.

3. 'Turkey, Libya Deals 'Void:' Egypt, France, Greece, Cyprus," Al Arabiya, (January 9, 2020), retrieved October 3, 2020, from https://english. alarabiya.net/en/News/north-africa/2020/01/09/ Turkey-Libya-deals-void-Egypt-France-GreeceCyprus-.html.

4. "EU Condemns Turkey-Libya Deal Despite Accordance With Int'l Law," Daily Sabah, (December 13, 2019), retrieved October 3, 2020, from https:// www.dailysabah.com/diplomacy/2019/12/13/ eu-condemns-turkey-libya-deal-despite-accordance-with-intl-law.

5. Günerigök, "UN Registers Turkey-Libya Maritime Deal," Anadolu Agency.

6. Burak Dağ, "Turkey's Support for Libya Will Continue," Anadolu Agency, (October 2, 2020), retrieved October 4, 2020, from https://www. aa.com.tr/en/africa/turkeys-support-for-libya-will-continue/1993165https://www.aa.com.tr/ en/africa/turkeys-support-for-libya-will-continue/1993165.

7. "Turkey to Establish Military Base in Libya," Middle East Monitor, (December 18, 2019), retrieved October 5, 2020, from https://www.middleeastmonitor.com/20191218-turkey-to-establish-military-base-in-libya/.

8. Enes Canlı, “Libya: Haftar Use Daesh/ISIS Tactic While Withdrawing," Anadolu Agency, (May 23, 2020), retrieved October 6, 2020, from https:// www.aa.com.tr/en/middle-east/libya-haftar-usedaesh-isis-tactic-while-withdrawing/1851072.

9. "Libya's GNS Says Pro-Haftar Mercenaries Deployed in Jufra and Sirte Despite Ceasefire," Middle East Eye, (August 30, 2020), retrieved October 8, 2020, from https://www.middleeasteye.net/ news/libya-gna-military-pro-haftar-mercenaries-deployed-jufra-sirte-ceasefire.

10. Mücahit Aydemir, “Libya: Russian Plane Brings Syrian Fighters to Sirte," Anadolu Agency, (October 3, 2020), retrieved October 8, 2020, from https:// www.aa.com.tr/en/africa/libya-russian-planebrings-syrian-fighters-to-sirte/1994770.

11. "NOC Recognised as Sole Legitimate Libyan Oil Corporation by International Community," National Oil Corporation, retrieved October 8, 2020, from https://noc.ly/index.php/ en/new-4/3773-noc-recognised-as-sole-legitimate-libyan-oil-corporation-by-international-community. 
12. "Press Release Regarding the Signing of the Libyan Political Agreement," Republic of Turkey Ministry of Foreign Affairs, (December 18, 2015), retrieved October 9, 2020, from http://www. mfa.gov.tr/no_-308_-16-december-2015_-pressrelease-regarding-the-signing-ceremony-ofthe-libyan-political-agreement.en.mfa.

13. Ramy Allahoum, "Libya's War: Who Is Supporting Whom?" Al Jazeera, (January 9, 2020), retrieved October 9, 2020, from https://www. aljazeera.com/news/2020/1/9/libyas-war-who-issupporting-whom.

14. "Libya and the New Global Disorder: A Conversation with Ghassan Salamé," Carnegie Endowment, (October 15, 2020), retrieved October 20, 2020, from https://www.youtube.com/ watch?v=XPo1Mk67GoA\&t=1s\&ab_channel=CarnegieLive.

15. Brian Katz and Joseph S. Bermudez Jr., "Moscow's Next Front: Russia's Expanding Military Footprint in Libya," Center for Strategic International Studies, (June 17, 2020), retrieved October 9, 2020, from https://www.csis.org/analysis/moscows-next-front-russias-expanding-military-footprint-libya.

16. Mücahit Aydemir, "Haftar Losing Ground despite UAE Spending Fortune," Anadolu Agency, (May 21, 2020), retrieved October 10, 2020, from https://www.aa.com.tr/en/middle-east/haftarlosing-ground-despite-uae-spending-fortune-/ 1848499.

17. Aishwarya Rakesh, "Libyan Military Destroys Haftar Forces' Pantsir Air Defense System, Wing Loong Drones," Defense World, (May 18, 2020), retrieved October 11, 2020, from https://www. defenseworld.net/news/26999/Libyan_Military_ Destroys_Haftar_Forces____Pantsir_Air_Defense_Systems_Wing_Loong_Drones.

18. "Egypt Sends more Arms to Libya's Haftar," Middle East Monitor, (June 7, 2019), retrieved October 12, 2020, from https://www.middleeastmonitor.com/20190607-egypt-sends-more-arms-tolibyas-haftar/https://www.middleeastmonitor. com/20190607-egypt-sends-more-arms-to-libyas-haftar/.

19. "Turkish Parliament Ratifies Libya Troops Motion," Anadolu Agency, (January 2, 2020), retrieved
October 14, 2020, from https://www.aa.com. tr/en/turkey/turkish-parliament-ratifies-libya-troops-motion/1690396.

20. İsmail Numan Telci, "Why the Eastern Mediterranean Is of Strategic Importance for Turkey," Politics Today, (May 13, 2019), retrieved October 15, 2020, from https://politicstoday.org/why-theeastern-mediterranean-is-of-strategic-importance-for-turkey/.

21. İsmail Numan Telci, "Turkey's Quest for Influence in the Mediterranean in the Post-Arab Uprisings Era," in Robert Mason (ed.), Transnational Security Cooperation in the Mediterranean, (Cham: Palgrave, 2020), pp. 171-173.

22. "Turkey to Launch Oil Exploration in East Med Soon under Pact with Libyan Government," Daily Sabah, (May 29, 2020), retrieved October 18, 2020, from https://www.dailysabah.com/business/energy/turkey-to-launch-oil-exploration-ineast-med-soon-under-pact-with-libyan-government.

23. "Turkey's Foreign Minister Visits Libya for Talks with GNA," Al Jazeera, (June 17, 2020), retrieved October 18, 2020, from https://www.aljazeera. com/news/2020/6/17/turkeys-foreign-ministervisits-libya-for-talks-with-gna.

24. "Turkey-Libya Deal to Complete Unfinished Construction Projects Enters into Force," Daily Sabah, (October 16, 2020), retrieved October 18, 2020, from https://www.dailysabah.com/ business/economy/turkey-libya-deal-to-complete-unfinished-construction-projects-enters-into-force.

25. Alex Gatopoulos, "Largest Drone War in the World: How Airpower Saved Tripoli," Al Jazeera, (May 28, 2020), retrieved October 18, 2020, from https://www.aljazeera.com/news/2020/5/28/ largest-drone-war-in-the-world-how-airpowersaved-tripoli.

26. Çağatay Zontur, "Turkish Intel Helps Cross-Border Operations Succeed-Erdoğan," Anadolu Agency, (June 6, 2020), retrieved October 18, 2020, from https://www.aa.com.tr/en/turkey/ turkish-intel-helps-cross-border-operations-succeed/1694021 https://www.aa.com.tr/en/turkey/ turkish-intel-helps-cross-border-operations-succeed/1694021. 